\title{
Subacute sclerosing panencephalitis
}

\author{
JOHN H. CONNOLLY
}

From the Department of Microbiology, The Queen's University of Belfast, Belfast

Subacute sclerosing panencephalitis is a rare disease which predominantly affects children of school age. The diagnosis is made on the clinical features and the presence of periodic complexes in the electroencephalogram. There is a paretic colloidal gold curve in the cerebrospinal fluid but the cell count and protein are usually within normal limits. The histology of a brain biopsy taken during lifemay confirm the diagnosis.

The aetiology of subacute sclerosing pancencephalitis has remained obscure until recently and a conference was held in 1967 to review the evidence for a viral cause of the disease (Sever and Zeman, 1968). Recent experimental work using light and electron microscopy, virology, and immunology has extended the specificity of the laboratory diagnosis and these methods may also be applied to the investigation of other possible persistent viral infections.

Three boys with subacute sclerosing panencephalitis, aged 12 years, 15 years, and 17 years, were investigated by Connolly, Allen, Hurwitz, and Millar (1967). They had had measles at the ages of 8 months, 3 years, and 4 years respectively, which meant that there was a latent period of 11 to 13 years between their childhood measles and the onset of subacute sclerosing panencephalitis. The three boys died after illnesses lasting 17 months, six months, and three months respectively. The boys had no history of clinical measles in the months before the onset of the terminal illness and none had any contact with each other. They had not received either killed or live attenuated measles vaccines.

\section{Microscopy}

The histology of the brains of the three patients showed diffuse perivascular inflammation, neuronal degeneration, gliosis, and slight to severe demyelination. Eosinophilic nuclear and cytoplasmic inclusions were present in neurones and glial cells. The viral aetiology of subacute sclerosing panencephalitis was suggested by the finding of Cowdry type A nuclear inclusions in brain cells, which were first described by Dawson (1933), and these were present in the three patients. The methyl green-pyronin stain showed that the inclusions contained ribonucleic acid (RNA) which was consistent with an RNA virus such as measles being present. Deoxyribonucleic acid (DNA) could not be found in the inclusions by the Feulgen reaction, which excluded herpes simplex and varicella-zoster viruses which also produce Cowdry type A inclusions (Connolly, Allen, Hurwitz, and Millar, 1968).

Further support for the viral aetiology of subacute sclerosing panencephalitis came from electron microscopic studies by Bouteille, Fontaine, Vedrenne, and Delarue (1965) who found intranuclear tubular filaments in brain which resembled those seen in dog kidney cells infected with measles virus (Tawara, 1965). These observations have been confirmed by many others, and Herndon and Rubinstein (1968) proposed a developmental sequence leading from nucleoliform to multitubular inclusions in the nucleus and thence to cytoplasmic inclusions. It should be pointed out that it is impossible to identify a particular virus such as measles on electron microscopy alone, since its structure resembles that of other viruses of the paramyxovirus group such as distemper, rinderpest, mumps, parainfluenza types $1,2,3,4$, Newcastle disease virus, and the bovine and simian paramyxoviruses.

\section{Virology}

The first definite evidence linking measles virus with subacute sclerosing panencephalitis came from the observations of Connolly et al (1967) who found measles antigen in the brains of the three patients described above and measles antibody in their sera and cerebrospinal fluid. In the cerebral cortex of the three patients both nuclear and cytoplasmic measles specific staining was found in neurones and glial cells by the direct immunofluorescence test (Fig. 1). Oval or round fluorescent masses surrounded by a ring of fluorescent granules similar to type $\mathrm{A}$ inclusions were common and binucleate fluorescing cells, which were probably astrocytes, were also seen. There was no staining of the brains with conjugated anti- 

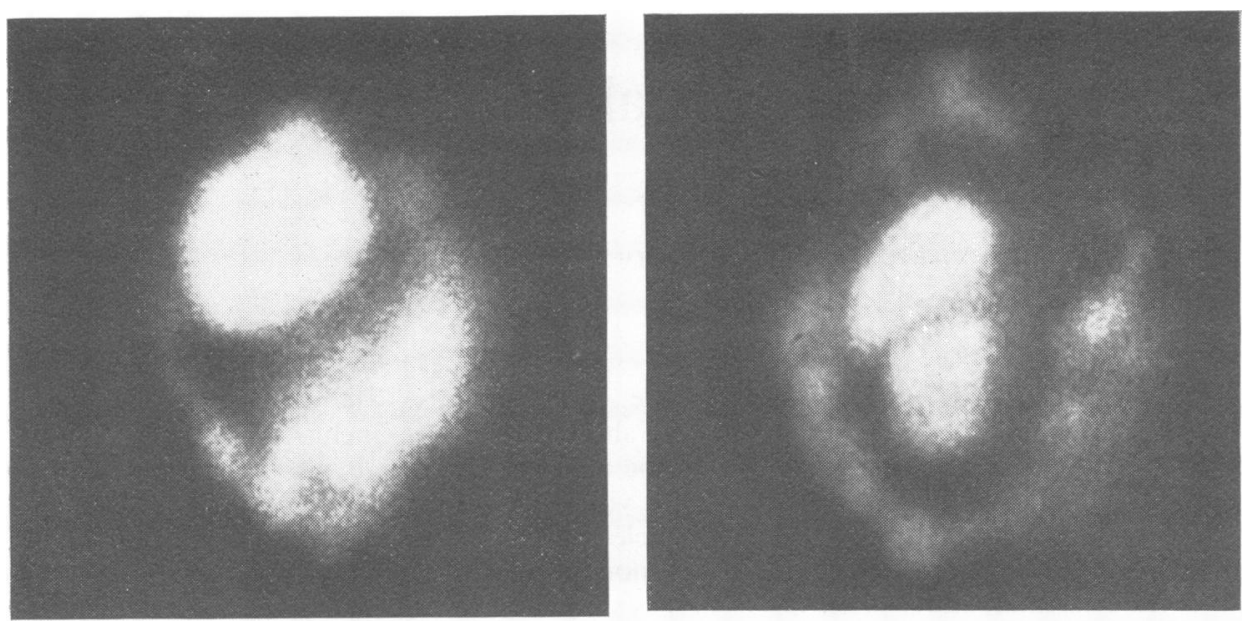

Fig. 1 Cells from left temporal cerebral cortex of patient 1 stained with goat anti-measles serum conjugated with fluorescein isothiocyanate. $\times 4800$

Left Cell showing nuclear and cytoplasmic fluorescence

Right Binucleate cell (probably an astrocyte) showing nuclear and some cytoplasmic fuorescence.

distemper serum(Connolly, 1968; Freeman, Magoffin, Lennette, and Herndon, 1967).

Many attempts have been made to isolate virus from the brain in this disease but without success until recently. There is one report of transmission of encephalitis from brain biopsy material to cynomolgous monkeys (Périer, Thiry, Vanderhaeghen, and Pelc, 1968) but Connolly et al (1967) were unable to isolate virus from the brains of the three patients with subacute sclerosing panencephalitis in rhesus monkeys, mice, or cell cultures. The difficulties in isolating measles virus from infected brain tissue include the defectiveness of the virus, and the existence in brain of specific inhibitors such as measles antibody and interferon. In addition a phospholipid inhibitor of measles virus which is present in normal human brain was recently described by Burnstein, Swango, and Byington (1971).

Katz, Rorke, Masland, Koprowski, and Tucker (1968) inoculated ferrets intracerebrally with brain suspensions from three children with subacute sclerosing panencephalitis and produced a subacute encephalitis in five months. Passage of infected ferret brain reproduced the disease in three months, but evidence of measles virus infection could not be found. Later Katz, Rorke, Masland, BarbantiBrodano, and Koprowski (1970) inoculated ferrets with subacute sclerosing panencephalitis brain cell cultures which produced encephalitis in only two weeks and was associated with evidence of measles virus infection. Koprowski, Barbanti-Brodano, and
Katz (1970) reported finding Papova-like particles (tumour viruses) in the cytoplasm of cultures of human brain cells from subacute sclerosing panencephalitis in addition to paramyxovirus (measles) nucleocapsids but it is not yet known whether the tumour virus particles were unobtrusive symbionts present in the brain tissue or if they are capable of causing disease with or without the help of measles virus.

Baublis and Payne (1968) described the occurrence of measles antigen and formation of syncytia in brain cell cultures of subacute sclerosing panencephalitis and the production of syncytia in several kinds of cultured cells when exposed to these brain cells, while Horta-Barbosa, Fuccillo, Sever, and Zeman (1969) isolated measles virus from subacute sclerosing panencephalitis brain by co-cultivation of cultures of brain biopsy fibroblasts with HeLa cells. A later report by Horta-Barbosa, Hamilton, Wittig, Fuccillo, Sever, and Vernon (1971) showed that suppressed measles virus infection in subacute sclerosing panencephalitis is not restricted to the brain alone. Measles virus was isolated by cocultivation of cultures of lymph node biopsies with HeLa cells from two patients in the early stages of the disease. Measles virus was not isolated by these techniques from three patients in the late stages of the disease or from five control patients. It is of interest that Dayan and Stokes (1971) found measles virus antigen by immunofluorescence in cells from cerebrospinal fluid in four patients with subacute 
sclerosing panencephalitis which suggests that cells of the lymphocyte or macrophage series are capable of carrying measles virus.

The viruses isolated from subacute sclerosing panencephalitis appear to be variants of measles virus when investigated either in cell cultures (Oyanagi, ter Meulen, Katz, and Koprowski, 1971) or when inoculated intracerebrally into hamsters (Lehrich, Katz, Rorke, Barbanti-Brodano, and Koprowski, 1970; Albrecht and Schumacher, 1971). It is not known if these variant viruses were 'wild' measles viruses which became modified after prolonged replication in brain or elsewhere in the presence of high titre measles antibody. Rustigian (1966) investigated a similar system in vitro and found that HeLa cells, which were persistently infected with measles virus and grown in the presence of measles antibody, failed to produce infectious virus but synthesis of incomplete virus continued even when the cells were cultured thereafter in antibody free medium.

\section{LIVE MEASLES VACCINE}

It is disturbing that six children have been reported who developed subacute sclerosing panencephalitis three weeks, five months, one year (two children), and three years (two children) respectively after immunization with live attenuated measles vaccine (Schneck, 1968; Payne, Baublis, and Itabashi, 1969; Parker, Klintworth, Graham, and Griffith, 1970; Gerson and Haslam, 1971; Furesz, 1971). It is therefore essential that careful and prolonged surveillance is maintained on all children who receive the vaccine since this rare complication may not appear until several years later.

Webb, Illavia, and Laurence (1971) have propagated measles virus vaccine strains in cultures of non-neuronal cells of human foetal brain and infectious virus was produced for up to 76 days after inoculation. The infected cells proliferated more rapidly than controls but there is no evidence that measles virus produces similar glial proliferation in vivo which might lead to subacute sclerosing panencephalitis.

\section{Immunology}

Measles antibody was found in the serum and cerebrospinal fluid of three patients with subacute sclerosing pancencephalitis (Connolly et al, 1967). The measles complement-fixing (CF) and haemagglutination-inhibiting (HI) antibody was at high titre in the serum of two patients and in one patient the titres increased 16 fold during the course of the illness, which indicated an active infection. The titre of measles antibody was much higher than that which follows childhood measles. These findings have since been confirmed by many other investigators (Sever and Zeman, 1968).

Legg (1967) recorded a patient with subacute sclerosing panencephalitis who made a good recovery where the measles complement-fixing antibody fell to undectable levels four years later but the haemagglutination-inhibiting antibody titre had not altered significantly. Serial measles complementfixation antibody tests may therefore have prognostic value in this disease.

The ratio of measles antibody in serum and cerebrospinal fluid samples taken simultaneously from the same patient was of some interest (Table I). It was found by Clarke, Dane, and Dick (1965) that there is a ratio ranging from $256: 1$ to $2048: 1$ with a geometric mean ratio of 505:1 between the titre of poliovirus antibody in the serum and in the cerebrospinal fluid of healthy people. It will be seen that when poliovirus type 2 antibody was used as a marker for an intact blood-brain barrier in the three patients described above, the poliovirus type 2 serum/ cerebrospinal fluid antibody ratios were within normal limits which excluded contamination of the cerebrospinal fluid with blood when the samples were taken or a non-specific 'leak' of serum antibody into the cerebrospinal fluid. The measles serum/ cerebrospinal fluid antibody ratios, on the other

\begin{tabular}{|c|c|c|c|c|c|c|c|c|}
\hline \multirow[t]{2}{*}{ Patient } & \multirow[t]{2}{*}{ Month of Illness } & \multirow[t]{2}{*}{$\begin{array}{l}\lg G(\mathrm{mg}) / \\
100 \mathrm{ml} \mathrm{CSF}\end{array}$} & \multicolumn{2}{|c|}{$\begin{array}{l}\text { Reciprocal of Measles } \\
\text { Antibody Titre }\end{array}$} & \multicolumn{2}{|c|}{$\begin{array}{l}\text { Reciprocal of Poliovirus } \\
\text { Type } 2 \text { Antibody Titre }\end{array}$} & \multirow{2}{*}{$\begin{array}{l}\text { Measles } \\
\text { Serum/CSF } \\
\text { Antibody } \\
\text { Ratio }\end{array}$} & \multirow{2}{*}{$\begin{array}{l}\text { Poliovirus Type } \\
2 \text { Serum/CSF } \\
\text { Antibody Ratio }\end{array}$} \\
\hline & & & Serum & CSF & Serum & CSF & & \\
\hline $\begin{array}{l}1 \\
2 \\
3\end{array}$ & $\begin{array}{r}12 \mathrm{th} \\
4 \mathrm{th} \\
3 \mathrm{rd}\end{array}$ & $\begin{array}{r}13 \\
10 \cdot 5 \\
6 \cdot 6\end{array}$ & $\begin{array}{r}2048 \\
1024 \\
64\end{array}$ & $\begin{array}{r}128 \\
64 \\
16\end{array}$ & $\begin{array}{r}362 \\
1448 \\
362\end{array}$ & $\begin{array}{l}<2 \\
<2 \\
<2\end{array}$ & $\begin{array}{r}16 \\
16 \\
4\end{array}$ & $\begin{array}{l}>181 \\
>724 \\
>181\end{array}$ \\
\hline
\end{tabular}

Table I Measles virus haemagglutination-inhibiting antibody and poliovirus type 2 neutralizing antibody in the serum and cerebrospinal fluid of three patients with subacute sclerosing panencephalitis 
hand, were much lower which indicated that measles antibody may be produced or released inside the central nervous system in subacute sclerosing panencephalitis (Connolly, 1968).

Connolly, Haire, and Hadden (1971) extended these observations and measured measles specific immunoglobulin $\mathbf{M}$ (IgM) and immunoglobulin $\mathbf{G}$ (IgG) responses in 10 children with measles and in the three patients with subacute sclerosing panencephalitis. In the children with measles the measles IgG rose quickly and persisted but the measles IgM response had disappeared by the 46th day following the onset of the rash. Measles $\operatorname{IgM}$ and IgG were not detected in cerebrospinal fluid from five normal patients. The patients with subacute scleresing panencephalitis, on the other hand had abnormally high serum titres of measles $\operatorname{IgM}$ and IgG and both measles IgM and IgG were present in the cerebrospinal fluid. The measles IgM persisted during prolonged illnesses in serum and cerebrospinal fluid which suggested a correlation with the known persistence of measles virus antigen in the brains of the three patients. It was concluded from the measles IgM and IgG serum/cerebrospinal fluid ratios that both measles IgM and IgG may be produced within the central nervous system in subacute sclerosing panencephalitis. Tourtellotte, Parker, Herndon, and Cuadros (1968) observed that IgG was increased in the brain of a patient with subacute sclerosing panencephalitis and that about $95 \%$ of the brain IgG was due to local synthesis in the brain. It will be seen from Table I that the total IgG in the cerebrospinal fluid was increased in the three patients. The origin of the antibody inside the central nervous system is the subject of much speculation but it presumably comes from the perivascular mononucleated cells in the brain or in the meninges. It is unlikely that much antibody was derived from cells in the cerebrospinal fluid since the cell count in the three cases was within normal limits.

It is not known if measles antibody damages brain cells containing measles antigen but Minagawa and Yamada (1971) described the immunolysis of HeLa cells persistently infected with measles virus and showed that the cytotoxic effects required measles antibody and complement which also indicated the existence of viral surface antigen.

Saunders, Knowles, Chambers, Caspary, GardnerMedwin, and Walker (1969) found specific changes in cell-mediated immunity in a boy with subacute sclerosing panencephalitis whose lymphocyte transformation in response to measles antigen was strikingly increased when compared with a healthy matched control. Both boys had had measles. They postulated that immuno-competent lymphocytes specific for measles antigen may interact destructively with host cells in the brain and that this may lead to subacute sclerosing panencephalitis.

Burnet (1968) postulated that subacute sclerosing panencephalitis is the consequence of a persistent measles infection in a person who has developed measles specific tolerance in his thymus-dependent (T) lymphocytes (responsible for delayed type hypersensitivity) but normal responsiveness in his gut-associated (B) lymphocytes (responsible for antibody). Tolerance could be due to a persistent measles infection of the patient's thymus concurrent with the infection of the central nervous system. However, measles virus could not be isolated from the thymus of a patient with subacute sclerosing panencephalitis (Fuccillo, Horta-Barbosa, and Sever, 1969) or seen in the thymus of two other patients by immunofluorescence (Connolly, unpublished) and lymphocyte transformation in response to measles antigen was increased in a boy with the disease (Saunders et al, 1969). On the other hand, Gerson and Haslam (1971) reported four boys with subacute sclerosing panencephalitis who did not express delayed type responses to six common skin test antigens (including measles); skin allografts were rejected more slowly than normal and contact sensitivity to dinitrochlorobenzene failed to develop. It would be unwise to draw any definite conclusions from the investigation of such a small number of cases but if the results are confirmed then the paradox of increased lymphocyte sensitization and greatly diminished delayed type skin hypersensitivity to measles virus in subacute sclerosing panencephalitis may possibly be explained by postulating a serum factor capable of depressing lymphocyte response (Field and Caspary, 1971).

Non-specific changes in serum and cerebrospinal fluid immunoglobulins and autoantibody in serum and cerebrospinal fluid directed against affected brain have also been described in subacute sclerosing panencephalitis (Kolar, 1968; Gerson and Haslam, 1971). Since measles virus matures at and buds through the cell membrane, it is conceivable that either the cell wall is altered antigenically during infection or that the released virus contains some cell wall antigen. In either case locally produced antibody could react not only with measles virus but also with brain cell membranes. It must be stressed that antibody or cell-mediated immunity directed against either measles virus or brain cells is not yet known to play any part in producing the pathological changes of subacute sclerosing panencephalitis.

\section{Summary}

A review of experimental work on subacute sclerosing panencephalitis indicates that this rare disease 
results from a persistent measles virus infection associated with an abnormal immunological response of the patient.

The virological and immunological investigations of the three patients with subacute sclerosing panencephalitis in N. Ireland would have been impossible without the valuable contributions of $\mathrm{Dr}$ Ingrid V. Allen who carried out the pathological studies and Dr J. H. D. Millar and the late Dr L. J. Hurwitz who investigated the patients clinically. I also thank Professor K. B. Fraser and Dr Margaret Haire who helped with the immunofluorescence and Dr T. A. McNeill who reviewed the manuscript.

\section{References}

Albrecht, P., and Schumacher, H. P. (1971). Neurotropic properties of measles virus in hamsters and mice. J. Infect. Dis., 124, 86-93.

Baublis, J. V., and Payne, F. E. (1968). Measles antigen and syncytium formation in brain cell cultures from subacute sclerosing panencephalitis. Proc. Soc. exp. Biol. (N.Y.), 129, 593-597.

Bouteille, M., Fontaine, C., Vedrenne, C., and Delarue, J. (1965) Sur un cas d'encephalite subaiguë à inclusions; étude anatomoclinique et ultrastructurale. Rev. neurol., 113, 454-458.

Burnet, F. M. (1968). Measles as an index of immunological function. Lancet, 2, 610-613.

Burnstein, T., Swango, L. J., and Byington, D. P. (1971). Non-specific brain inhibitor against measles virus. Arch. ges. Virusforsch. 34, 396-399.

Clarke, J. K., Dane, D. S., and Dick, G. W. A. (1965). Viral antibody in the cerebrospinal fluid and serum of multiple sclerosis patients. Brain, 88, 953-962.

Connolly, J. H. (1968). Additional data on measles virus antibody and antigen in subacute sclerosing panencephalitis. Neurology (Minneap.), 18, no. 1, pt 2, 87-89.

Connolly, J. H., Allen, I. V., Hurwitz, L. J., and Millar, J. H. D. (1967). Measles virus antibody and antigen in subacute sclerosing panencephalitis, Lancet, 1, 542-544.

Connolly, J. H., Allen, I. V., Hurwitz, L. J., and Millar, J. H. D. (1968). Subacute sclerosing panencephalitis: clinical, pathological, epidemiological and virological findings in three patients. Quart.J. Med., 37, 625-644.

Connolly, J. H., Haire, M., and Hadden, D. S. M. (1971). Measles immunoglobulins in subacute sclerosing panencephalitis. Brit. med. $J ., 1,23-25$.

Dawson, J. R., Jr. (1933). Cellular inclusions in cerebral lesions of lethargic encephalitis. Amer. J. Path., 9, 7-15.

Dayan, A. D., and Stokes, M. I. (1971). Immunofluoreszent detection of measles virus antigens in cerebrospinal fluid cells in subacute sclerosing panenephalitis. Lancet, 1, 891-892.

Field, E. J., and Caspary, E. A. (1971). Lymphocyte response depressive factor in multiple sclerosis. Brit med. J., 4, 529-532.

Freeman, J. M., Magoffin, R. L., Lennette, E. H., and Herndon, R. M. (1967). Additional evidence of the relation between subacute inclusion-body encephalitis and measles virus. Lancet, 2 , 129-131.

Fuccillo, D. A., Horta-Barbosa, L., and Sever, J. L. (1969). Subacute sclerosing panencephalitis. (Letter) Lancet, 1, 1101.

Furesz, J. (1971). Serologic diagnosis of measles in subacute sclerosing panencephalitis. New Engl. J. Med., 284, 729-730.

Gerson, K. L., and Haslam, R. H. A. (1971). Subtle immunologic abnormalities in four boys with subacute sclerosing panencephalitis. New Engl.J. Med., 285, 78-82.
Herndon, R. M., and Rubinstein, L. J. (1968). Light and electron microscopy observations on the development of viral particles in the inclusions of Dawsons encephalitis (subacute sclerosing panencephalitis). Neurology (Minneap.), 18, no. 1, pt 2, 8-18.

Horta-Barbosa, L., Fuccillo, D. A., Sever, J. L., and Zeman, W. (1969) Subacute sclerosing panencephalitis: isolation of measles virus from a brain biopsy. Nature (Lond.), 221, 974

Horta-Barbosa, L., Hamilton, R., Wittig, B., Fuccillo, D. A., Sever, J. L., and Vernon, M. L. (1971). Subacute sclerosing panencephalitis: isolation of suppressed measles virus from lymph node biopsies. Science, 173, 840-841.

Katz, M., Rorke, L. B., Masland, W. S., Barbanti-Brodano, G., and Koprowski, H. (1970). Subacute sclerosing panencephalitis; isolation of a virus encephalitogenic for ferrets. J. inf. Dis., 121, 188-195.

Katz, M., Rorke, L. B., Masland, W. S., Koprowski, H., and Tucker, S. H. (1968). Transmission of an encephalitogenic agent from brains of patients with subacute sclerosing panencephalitis to ferrets. New. Engl. J. Med., 279, 793-798.

Kolar, O. (1968). Immunopathologic observations in subacute sclerosing panencephalitis. Neurology (Minneap.), 18, no. 1, pt $2,107-111$.

Koprowski, H., Barbanti-Brodano, G., and Katz, M. (1970). Interaction between Papova-like virus and paramyxovirus in human brain cells: a hypothesis. Nature (Lond.), 225, 1045-1047.

Legg, N. J. (1967). Virus antibodies in subacute sclerosing panencephalitis: a study of 22 patients. Brit. med. J., 3, 350-352.

Lehrich, J. R., Katz, M., Rorke, L. B., Barbanti-Brodano, G., and Koprowski, H. (1970). Subacute sclerosing panencephalitis: Encephalitis in hamsters produced by viral agents isolated from human brain cells. Arch. Neurol., 23, 97-102.

Minagawa, T., and Yamada, M. (1971). Studies of the persistent infection with measles virus in HeLa cells. III. Immunolysis of cells in carrier state by anti-measles sera. Jap. J. Microbiol., 15 , 341-350.

Oyanagi, S., ter Meulen, V. Katz, M., and Koprowski, H. (1971). Comparison of subacute sclerosing panencephalitis and measles viruses: an electron microscope study. J. Virol., 7, 176-187.

Parker, J. C., Jr., Klintworth, G. K., Graham, D. G., and Griffith, J. F. (1970). Uncommon morphologic features in subacute sclerosing panencephalitis. Amer. J. Path., 61, 275-292.

Payne, F. E., Baublis, J. V., and Itabashi, H. H. (1969). Isolation of measles virus from cell cultures of brain from a patient with subacute sclerosing panencephalitis. New Engl. J. Med., 281, 585-589.

Perier, O., Thiry, L., Vanderhaeghen, J. J., and Pelc, S. (1968) Attempts at experimental transmission and electron microscopic observations in subacute sclerosing panencephalitis. Neurology (Minneap.), 18, no. 1, pt 2, 138-143.

Rustigian, R. (1966). Persistent infection of cells in culture by measles virus. II. Effect of measles antibody on persistently infected HeLa sublines and recovery of a HeLa clonal line persistently infected with incomplete virus. J. Bact., 92, 1805-1811.

Saunders, M., Knowles, M., Chambers, M. E., Caspary, E. A. Gardner-Medwin, D., and Walker, P. (1969). Cellular and humoral responses to measles in subacute sclerosing panencephalitis. Lancet, 1, 72-74.

Schneck, S. A. (1968). Vaccination with measles and central nervous system disease. Neurology (Minneap.), 18, no. 1, pt 2, 79-82.

Sever, J. L., and Zeman, W., eds. (1968). Conference on measles virus and subacute sclerosing panencephalitis. Neurology (Minneap.), 18, no. 1, pt 2, 1-192.

Tawara, J. (1965). Fine structure of filaments in dog kidney cell cultures infected with measles virus. Virology, 25, 322.

Tourtellotte, W. W., Parker, J. A., Herndon, R. M., and Cuadros, C. V. (1968). Subacute sclerosing panencephalitis: brain immunoglobulin G, measles antibody and albumin. Neurology (Minneap.), 18, no. 1, pt 2, 117-121.

Webb, H. E., Illavia, S. J., and Laurence, G. D. (1971). Measles-vaccine viruses in tissue culture of non-neuronal cells of human feta brain. Lancet, 2, 4-5. 